\title{
Influencers on Instagram and YouTube and Their Impact on Consumer Behaviour
}

\author{
Bianka Młodkowska \\ Faculty of Management, University of Warsaw, Warsaw, Poland \\ 377477@wz.uw.edu.pl
}

Received: 27 March 2019/ Revised: 13 May 2019/ Accepted: 20 May 2019/ Published online: 19 June 2019

\begin{abstract}
Nowadays we are faced with a growing number of people using social media. The most popular of these are YouTube and Instagram. Their users are exposed to the content generated by influencers - social media creators with loyal audiences. The aim of this paper is to investigate the impact that influencers on Yotube and Instagram have on consumer behaviour. The research method employed in this study was a quantitative survey on the sample of 160 social media users. 160 individuals answered an online questionnaire. The results of the survey showed that Instabloggers and YouTubers are seen as a credible source of information and consumers find them trustworthy. Moreover, positive reviews on YouTube and pictures posted on Instagram affect consumers buying decisions. The results of the research suggest that engaging influencers to collaborate with brands is a new effective marketing tool which is especially efficient in reaching young people who use social media every day. Collaboration with influencers can result in gaining new customers, sharing positive information about new products and increasing sales.
\end{abstract}

JEL classification: M31, M37

Keywords: influencers, consumer behaviour, social media.

\section{INTRODUCTION}

The statistics show that there were more than 4 billion Internet users in June 2018 (Internet World Stats, 2018). In the Internet area, social media have become significantly popular among people around the world. The number of those having an Instagram or YouTube account is also growing. Not only do they use those sites to post their own pictures and videos, but also to interact with brands and products (Phua \& Ahn, 2016) and to exchange reviews about them (Zalega, 2013). Consumers can talk about products with both friends and strangers (Vinerean et al., 2013, p. 66). Social media are used as a way of communication, particularly between peers, and have a great influence on their buying decisions as well as on marketing strategies (Vinerean et al., 2013, p. 66). Consequently, social media have changed the way of communication between brands and consumers (Vinerean et al., 2013, p. 66) as they enable direct and two-way communication. Now, individuals can react to brand content instead of only absorbing information as it used to be before. What is more, they are active creators of brand content (Stewart \& Pavlou, 2002). They are engaged in marketing done by brands, which is influenced by more aware consumers (Heinonen 2011, p. 356). 
Social media have an impact on consumer behaviour and brands. As a result, marketing tools have been changed. For businesses, it is a unique opportunity to encourage prospects and regular consumers to be engaged in social media in order to build a personal relationship with them (Mersey et al., 2010). Instagram and YouTube are examples of social media. They bring together Internet users who upload their private content there and also communicate with others about brands and products. Social media have changed modern consumers and created influencers whose videos and pictures reach people in nearly all countries.

The aim of this study is to investigate the impact of influencers from Instagram and YouTube on consumer behaviour. The paper tries to give answers to the following three questions: Are influencers seen as a credible source of information concerning buying decisions? Do YouTubers' positive reviews impact buying decisions of viewers? Do Instabloggers' posted pictures and videos of products influence buying decisions of followers? A literature review and a qualitative study in the form of an online survey were conducted to answer these questions.

The paper is constructed as follows: in the first part, the theoretical background, hypotheses, the research model and empirical results are described. In the second part, conclusions and study limitations are presented. In the last part, all used references are listed.

\section{THEORETICAL BACKGROUND, HYPOTHESES, RESEARCH MODEL, EMPIRICAL RESULTS}

\subsection{Literature Review}

\subsubsection{Instagram and YouTube as Places of Influencer Marketing}

Instagram was launched in 2010 by Kevin Systrom and Mike Krieger (Instagram Press, 2019). The number of users reached over 1 billion in June 2018. More than 500 million users use Instagram every day (Instagram Press, 2019). Those daily actives are undertaken by people who not only scroll the application passively but also like, comment, share or post their own pictures.

What makes Instagram such a successful app? First of all, it was made for smartphones in order to make posted pictures easily viewed on small screens. So, there is no need for enlarging or minimising pictures. Secondly, we can associate Instagram with the most popular social media - Facebook. Indeed, there are many similarities between these two portals. In both cases, users are able to create profiles, post pictures and follow interesting people. The famous "thumbs up" was replaced by a heart, which has exactly the same meaning - users are fond of a picture or, from 2013, a short video (Instagram Press, 2019). To make a post famous and easy to find among billions of pictures, it can be marked with a short description, localisation, and a hashtag (represented by “\#”). Moreover, it can be marked with another profile or even a brand, which feature enables users to share the sources of their latest purchases and create e-WOM.

The growing popularity of Instagram has created a new type of bloggers. They post only using the app without having an additional site on WordPress or Blogger. To make a profile profitable, they are eager to collaborate with brands which send their products to users with a high number of followers. Then, Instabloggers post a picture with a product, for instance, a coat or a face cream, and finally they mark a brand. Followers may see what kind of products influencers use. An actress and singer, highly popular among Millennials, Selena Gomez has got over 6 million likes, or rather hearts, for a picture showing her drinking Coca-Cola beverage.

YouTube is the second social media site I have chosen to investigate the impact of influencers. The portal was established by Chad Hurley, Steve Chen and Jawed Karim in 2005. The site enables users to view, comment and upload a variety of videos (Dehghani et al., 2016, p. 165). YouTube combines entertainment and professional contents in a video form. Moreover, it can be 
used as a marketing tool to create brand-consumer communication and a brand image (Wyrwisz \& Żydek, 2016, pp. 413-414).

YouTube offers all kind of videos: from music videos, movie trailers to lifestyle content like travelling, makeup, and video games. A user's site is called a channel and its popularity is measured by a number of subscribers, people who follow posted videos. For instance, we can find channels of famous singers (Rihanna VEVO), magazines (British Vogue) and brands (Porsche). Brands upload advertisements (Chanel), videos about their history (Burberry), and short videos of new products (Citroën).

Similarly to Instagram, anyone who has an account can try to become a popular vlogger. This term comes from a word blogger; the main difference between bloggers and vloggers is that instead of writing posts, an author uploads short films (SJP, 2018). So, YouTubers can be definitely seen as vloggers. Many people post on the site different kinds of content - gaming, fashion, beauty, travelling and many more. They represent all age groups, countries and interests. Many brands are looking for vloggers who are ready to collaborate and promote their products. As an example, we can take Zoella's channel. Zoella is a British beauty and lifestyle YouTuber with nearly 11.855,000 subscribers (YouTube Zoella, 2019). On her channel, we find videos in which she shows bought cosmetics and clothes (known as hauls). Those are seen by more than 1 million people. She also reviews products that she got from brands for free (reviews and opening boxes). Subscribers can participate in many competitions by sharing or commenting on a video to win reviewed products. We can conclude that by sharing opinions about products, viewers may follow influencers' buying decisions. The research conducted by Deghani et al. (2016, p. 170) demonstrated that YouTube advertising has great effects on the consumer purchase intention.

Thanks to regular publications and interactions, YouTubers and viewers start having a close mutual bond. Videos showing daily routine, honest reviews and answering subscribers' questions make influencers seen as friends. People sometimes know them better than their acquaintances as they are able to follow their life. Solomon, Bamossy, Askegaard and Hog (2016) claim that we absorb information coming from our friends more easily. As a result, those looking for advice will look for vloggers' videos. Furthermore, many immediate interactions occur because blogs, and also vlogs, are two-way communication channels, unlike commercial advertisements (Bernoff \& Li, 2008).

\subsection{2. $e W o M$}

Word of mouth or WOM is an informal way of exchanging information from person to person none of whom is a marketer (Blythe, 2013, p. 22). Richin and Root-Shaffer (1988) say that word of mouth is an important part of customer buying decisions. WOM is based on communication between families, friends and others in a social network. It may represent positive or negative content and is also a form of communication among current or potential customers and independent specialists (Ennew et al., 2000). When it comes to which opinion - either positive or negative one - has a greater influence on people, there are doubts. In research done by Herr, Kardes and Kim (1991), negative comments had a stronger effect than positive ones. The same result was confirmed by Wangenheim (2005). However, Liu (2006) reported different findings. According to her studies, negative comments may not only have no effects on the sales of a product but they also can result in promoting it.

Positive eWOM is seen as a powerful marketing tool for companies as a way to influence customers (Jensen et al., 2009, p. 2169). Interestingly, people trust word-of-mouth marketing more than any other kind of marketers' tools (Wiley, 2016, p. 31). Studies have shown that eWOM is perceived as more trustworthy and persuasive than traditional media, such as TV advertising and print ads (Cheung \& Thadani, 2012, p. 462). Moreover, the findings of the research carried out by Hsu, Lin and Chiang (2013, p. 69) suggest that sales can be increased by using bloggers' electronic word of mouth as it is a promising marketing strategy. Bloggers and vloggers can post 
reviews on their sites (Instagram) and channels (YouTube) by doing videos about a product or taking pictures of it. Researchers explored the consequences of eWOM and found that it impacts buying decisions and attitudes toward a featured product (Christodoulides et al., 2012; Lee \& Youn, 2009). It also has an influence on the willingness to recommend a product (Sun et al., 2006). One of the forms of eWOM is influencer marketing.

\subsubsection{Influencer Marketing}

Development of social media has created influencer marketing. Wiley (2016, p. 30) describes it as "the art and science of engaging people who are influential online to share brand messaging with their audiences in the form of sponsored content". Their biggest advantage lies in the possibility to employ everyday people as brand advocates who consumers find easier to identify with (Belch \& Belch, 2011). Internet, especially social media, can make every user a credible opinion leader whose reviews impact their followers. The biggest achievement for a company is to find an appropriate person to establish successful collaboration.

In comparison to traditional advertisement like ads on TV, consumers find opinions posted on blogs more credible (Haugstvedt, 2005), more useful and trustworthy (Johnson \& Kaye, 2009), and more reliable and valuable than commercial information (Wu, 2011). Furthermore, consumers trust bloggers more than brands because they communicate with them directly, describing their own experience with a product (Wu \& Wary, 2011). Doyle points out that many customers buy certain products purely and simply because they were reviewed on the blog before.

Sponsored posts on Instagram and films on YouTube and sending products to the influencers are examples of influencer marketing. The effectiveness of these actions is dependent on the way in which influencers communicate with followers. Wiley $(2016$, p. 31) mentions that the more freedom to share views about the brand an influencer has, the more credible, and as a result, more effective the brand message will be. The brand should allow the influencer to be authentic (Wiley, 2016, p. 31).

Lee and Watkins (2016) examined how vlogs influence consumer perception of a luxury brand. The results showed that people who had watched video reviews about luxury products, better perceived luxury brand and were more eager to buy its products than the experimental group, who had not watched vlogs. Consumers compare themselves to followed vloggers and because of their influence, they want to buy luxury products in order to reach the same social status. If marketers want to engage YouTube vloggers, they should look for those who share similar views and target an attractive consumer group full of prospects (Lee \& Watkins, 2016, p. 5757).

Collaboration with influencers can result in gaining new customers and sharing information about new products. Also, awareness of the brand can be built by working with them (Wiley, 2016, p. 38). The aim of influencer marketing is to engage real people whose messages are read and watched by customers and prospects. Still, many companies have problems with the proper use of this marketing tool. Hence, marketers should engage influencers in campaigns only if they are seen as a credible source of information. A popular way of choosing collaborators is to rely on factors such as the number of followers, the number of posts and videos seen daily, and the number of times posts are shared. However, marketers have to remember that online influence is about quality, not quantity of publications (Basille, 2009; Straley, 2010).

Many companies are eager to collaborate with influencers as they are aware of how credible they are regarded by their customers. Blog marketing, for instance, is seen as both inexpensive and fast way to reach a target audience (Halvorsen et al., 2013, p. 222). In order to find information about a product, customers used to visit blog sites and read the reviews. Nowadays, they watch YouTube videos and like pictures on Instagram with marked or tagged goods. Those are seen as non-commercial hence consumers find them authentic. To gain new consumers, marketers send to influencers giveaways-free products to be tasted and discount codes for products which can be used by their followers. Discount codes primarily can be found on Instagram. The watch company 
Daniel Wellington offers them willingly to popular social media users all around the world. Influencers do not have to be in top-ten most popular people on Instagram to get a free watch and a personalised discount code. We will find them on the account of a popular model Kendall Jenner (@kendalljenner around 105 million followers), a Polish fashion blogger Katarzyna Tusk (@ makelifeeasier_pl 313k followers) as well as on the account of a less popular blogger Aleksandra Jagłowska (@jaglowska 24k followers).

As a result of the literature review presented above, three hypotheses were established as follows:

- Hypothesis 1: Influencers on Instagram and YouTube are treated by consumers as credible sources of information.

- Hypothesis 2: Influencers on Instagram and YouTube have an impact on consumers' buying decisions.

- Hypothesis 3: The perceived credibility of influencers on Instagram and YouTube is related to the propensity to buy recommended products.

\subsection{Research Method}

The research method used to verify the hypotheses was a qualitative study in form of an online survey. The purposeful sampling was employed to reach the group of 160 social media users who follow influencers on YouTube and Instagram.

The research questionnaire had two parts. In the first part of the survey, individuals were asked to fill out the metrics and answer the questions concerning their overall activity on social media. In the second part, they had to evaluate items concerning Instagram and influencers publishing there. Each item was measured using a five-point Likert scale. YouTube and vloggers were topics of the third part of the survey. Four scales were created, each consisting of 4 items to measure the consumers' inclination to treat influencers on Instagram and YouTube as credible sources of information and their propensity to buy products recommended by influencers. The reliability statistics (coefficient alphas) for all four scales are presented in Table 1 and all are above the suggested threshold of 0.8 (Churchill and Peter, 1984).

\section{Table 1}

\begin{tabular}{ll}
\multicolumn{1}{c}{ Scales } & Cronbach's alpha \\
\hline Credibility of Instagram influencers scale & Alpha $=0.827$ \\
\hline Credibility of YouTube influencers scale & Alpha $=0.848$ \\
\hline Propensity to buy products recommended by influencers on Instagram scale & Alpha $=0.835$ \\
Propensity to buy products recommended by influencers on YouTube scale & Alpha $=0.897$
\end{tabular}
Source: own research

Among the respondents, women represented slightly above $80 \%$ of the total and men accounted for just under $20 \%$. The highest number of respondents were aged 20-24 years $(77.5 \%)$. In total, 160 individuals participated in this study.

\subsection{Empirical Results}

The conducted researched showed that $90.6 \%$ of participants use social media to communicate with friends a few times per day. Nearly all of them (97\%) use social media to follow others' 
activity and nearly $68 \%$ follow bloggers and vloggers. Interestingly, $88 \%$ of the individuals keep track of brands' activities on social media.

In Tables 2 and 3, the results of the study verifying hypothesis 1 are presented. When it comes to the credibility of influencers on Instagram (Table 2), the majority of respondents rather agreed that they willingly scroll pictures with marked brands/products posted by bloggers $(39.6 \%)$ and they willingly watch InstaStories posted with marked brands/products by bloggers they follow (41.7\%). 39.6\% of participants neither agreed nor disagreed with the statement that they find pictures in which bloggers recommend particular brands or products credible. Also, roughly $44 \%$ neither agreed nor disagreed that bloggers recommending particular brands are credible. As far as the credibility of influencers on YouTube is concerned (Table 3), nearly half of respondents rather agreed that they willingly watch videos posted by vloggers. Slightly fewer individuals $(40.2 \%)$ rather agreed that they willingly watch product reviews posted by vloggers. $34.3 \%$ of participants rather find vloggers' reviews credible, however, $36.3 \%$ neither agreed nor disagreed. Similarly, $33.3 \%$ rather find vloggers' videos on recommended brands and products interesting and nearly the same number of respondents neither agreed nor disagreed (32.4\%).

Despite having a high number of indecisive respondents, hypothesis 1 was confirmed and influencers' reviews are seen by most of respondents as a reliable source of information.

Table 2

Credibility of influencers on Instagram

\begin{tabular}{|c|c|c|c|c|c|}
\hline & $\begin{array}{l}\text { I totally } \\
\text { agree }\end{array}$ & $\begin{array}{l}\text { I rather } \\
\text { agree }\end{array}$ & $\begin{array}{l}\text { Neither agree } \\
\text { nor disagree }\end{array}$ & $\begin{array}{l}\text { I rather } \\
\text { disagree }\end{array}$ & $\begin{array}{l}\text { I totally } \\
\text { disagree }\end{array}$ \\
\hline $\begin{array}{l}\text { I willingly scroll pictures with marked brands/ } \\
\text { products posted by bloggers. }\end{array}$ & $19.8 \%$ & $39.6 \%$ & $27.1 \%$ & $8.3 \%$ & $5.2 \%$ \\
\hline $\begin{array}{l}\text { I willingly watch InstaStories posted with } \\
\text { marked brands/products by bloggers I follow. }\end{array}$ & $13.5 \%$ & $41.7 \%$ & $21.9 \%$ & $10.4 \%$ & $12.5 \%$ \\
\hline $\begin{array}{l}\text { I find pictures in which bloggers recommend } \\
\text { particular brands or products credible. }\end{array}$ & $4.2 \%$ & $20.8 \%$ & $39.6 \%$ & $20.8 \%$ & $14.6 \%$ \\
\hline $\begin{array}{l}\text { In my opinion, bloggers recommending } \\
\text { particular brands are credible. }\end{array}$ & $3.0 \%$ & $16.7 \%$ & $43.8 \%$ & $24.0 \%$ & $12.5 \%$ \\
\hline
\end{tabular}

Source: own research, $\mathrm{N}=160$.

Table 3

Credibility of influencers on YouTube

\begin{tabular}{|c|c|c|c|c|c|}
\hline & $\begin{array}{l}\text { I totally } \\
\text { agree }\end{array}$ & $\begin{array}{l}\text { I rather } \\
\text { agree }\end{array}$ & $\begin{array}{l}\text { Neither agree } \\
\text { nor disagree }\end{array}$ & $\begin{array}{l}\text { I rather } \\
\text { disagree }\end{array}$ & $\begin{array}{l}\text { I totally } \\
\text { disagree }\end{array}$ \\
\hline I willingly watch videos posted by vloggers. & $40.2 \%$ & $46.0 \%$ & $8.9 \%$ & $3.9 \%$ & $1.0 \%$ \\
\hline $\begin{array}{l}\text { I willingly watch product reviews posted by } \\
\text { vloggers. }\end{array}$ & $25.5 \%$ & $40.2 \%$ & $15.7 \%$ & $6.9 \%$ & $12.5 \%$ \\
\hline I find vloggers' reviews credible. & $9.8 \%$ & $34.3 \%$ & $36.3 \%$ & $12.7 \%$ & $6.9 \%$ \\
\hline $\begin{array}{l}\text { I find vloggers' videos on recommended } \\
\text { brands and products interesting. }\end{array}$ & $11.8 \%$ & $33.3 \%$ & $32.4 \%$ & $12.7 \%$ & $9.8 \%$ \\
\hline
\end{tabular}

Source: own research, $\mathrm{N}=160$.

Tables 4 and 5 present the research results verifying hypothesis 2 . When it comes to YouTube influencers (Table 4), most of respondents rather agreed that they happen to buy products reviewed by a vlogger (35.3\%), thanks to vlogs they found out about new/interesting brands and products $(39.2 \%)$ and they happen to buy products seen on vlogs $(35.3 \%)$. Interestingly, 34.3\% of individuals neither agreed nor disagreed that they often want to buy a product reviewed by 
a vlogger. As far as Instagram influencers are concerned (Table 5), we can see similar results - most of respondents rather agreed that they often want to buy a product appearing in a blogger's picture (38.5\%), check online sites of marked products in bloggers' pictures (34.4\%) and claim that thanks to marked brands in bloggers' pictures, they have found out about new and interesting brands and products $(32.3 \%)$. Moreover, $35.4 \%$ of participants totally agreed that they happen to buy products seen on bloggers' accounts. However, exactly $24 \%$ rather disagreed with this statement.

Taking into account those results, hypothesis 2 was confirmed and consumers' purchase decisions are impacted by influencers' reviews on YouTube and recommendations made on Instagram.

\section{Table 4}

Propensity to buy products recommended by influencers on YouTube

\begin{tabular}{|c|c|c|c|c|c|}
\hline & $\begin{array}{l}\text { I totally } \\
\text { agree }\end{array}$ & $\begin{array}{l}\text { I rather } \\
\text { agree }\end{array}$ & $\begin{array}{l}\text { Neither agree } \\
\text { nor disagree }\end{array}$ & $\begin{array}{l}\text { I rather } \\
\text { disagree }\end{array}$ & $\begin{array}{l}\text { I totally } \\
\text { disagree }\end{array}$ \\
\hline $\begin{array}{l}\text { I often want to buy a product reviewed by } \\
\text { a vlogger. }\end{array}$ & $11.8 \%$ & $26.5 \%$ & $34.3 \%$ & $16.7 \%$ & $10.8 \%$ \\
\hline $\begin{array}{l}\text { I happen to buy products reviewed by } \\
\text { a vlogger. }\end{array}$ & $13.7 \%$ & $35.3 \%$ & $14.7 \%$ & $18.6 \%$ & $17.6 \%$ \\
\hline $\begin{array}{l}\text { Thanks to vlogs, I've found out about } \\
\text { new/interesting brands and products. }\end{array}$ & $34.3 \%$ & $39.2 \%$ & $9.8 \%$ & $10.8 \%$ & $5.9 \%$ \\
\hline I happen to buy products seen on vlogs. & $13.7 \%$ & $35.3 \%$ & $14.7 \%$ & $18.6 \%$ & $17.6 \%$ \\
\hline
\end{tabular}

Source: own research, $\mathrm{N}=160$.

Table 5

Propensity to buy products recommended by influencers on Instagram

\begin{tabular}{|c|c|c|c|c|c|}
\hline & $\begin{array}{l}\text { I totally } \\
\text { agree }\end{array}$ & $\begin{array}{l}\text { I rather } \\
\text { agree }\end{array}$ & $\begin{array}{l}\text { Neither agree } \\
\text { nor disagree }\end{array}$ & $\begin{array}{l}\text { I rather } \\
\text { disagree }\end{array}$ & $\begin{array}{l}\text { I totally } \\
\text { disagree }\end{array}$ \\
\hline $\begin{array}{l}\text { I often want to buy a product appearing in } \\
\text { a blogger's picture. }\end{array}$ & $6.3 \%$ & $38.5 \%$ & $21.9 \%$ & $17.7 \%$ & $15.6 \%$ \\
\hline $\begin{array}{l}\text { I check online sites of marked products in } \\
\text { bloggers' pictures. }\end{array}$ & $12.5 \%$ & $34.4 \%$ & $18.8 \%$ & $21.9 \%$ & $12.5 \%$ \\
\hline $\begin{array}{l}\text { Thanks to marked brands in bloggers' } \\
\text { pictures, I've found out about new and } \\
\text { interesting brands and products. }\end{array}$ & $32.3 \%$ & $44.8 \%$ & $6.3 \%$ & $10.4 \%$ & $6.3 \%$ \\
\hline $\begin{array}{l}\text { I happen to buy products seen on bloggers' } \\
\text { accounts. }\end{array}$ & $35.4 \%$ & $16.7 \%$ & $13.5 \%$ & $24.0 \%$ & $10.4 \%$ \\
\hline
\end{tabular}

Source: own research, $\mathrm{N}=160$

To test the 3rd hypothesis concerning the influence of perceived credibility of influencers on Instagram and YouTube and propensity to buy recommended products, a regression analysis was performed (see: Table 6). In the case of both analysed social media, the impact of perceived credibility on propensity to buy recommended products is significant and strong $(B=0.572$ for Instagram and $\mathrm{B}=0.693$ for YouTube). 
Table 6

Results of regression analysis

\begin{tabular}{|c|c|c|c|c|c|c|}
\hline \multirow{2}{*}{ Model } & \multicolumn{2}{|c|}{ Unstandardised Coefficients } & $\begin{array}{c}\text { Standardised } \\
\text { Coefficients }\end{array}$ & \multirow{2}{*}{$\mathrm{t}$} & \multirow{2}{*}{ p } & \multirow{2}{*}{ R2 } \\
\hline & B & Std. Error & Beta & & & \\
\hline \multicolumn{7}{|c|}{ Perceived credibility of influencers on Instagram $\rightarrow$ Propensity to buy recommended products } \\
\hline Constant & 1.256 & 0.315 & & 3.984 & 0.0001 & \multirow[b]{2}{*}{0.327} \\
\hline $\begin{array}{l}\text { Perceived credibility } \\
\text { of influencers on } \\
\text { Instagram }\end{array}$ & 0.656 & 0.097 & 0.572 & 6.754 & 0.0001 & \\
\hline \multicolumn{7}{|c|}{ Perceived credibility of influencers on YouTube $\rightarrow$ Propensity to buy recommended products } \\
\hline Constant & 0.131 & 0.338 & & 0.388 & 0.698 & \multirow[b]{2}{*}{0.480} \\
\hline $\begin{array}{l}\text { Perceived credibility } \\
\text { of influencers on } \\
\text { YouTube }\end{array}$ & 0.877 & 0.091 & 0.693 & 9.601 & 0.0001 & \\
\hline
\end{tabular}

\section{CONSLUSIONS, STUDY LIMITATIONS}

The results of my research show that influencers are an important part of customers' buying decisions. Instabloggers and YouTubers are seen as a credible source of information and consumers find them trustworthy. They rely on their reviews and posted pictures, videos with marked brands. My conclusions can be used especially by marketers who want to make effective use of social media to promote brands and increase sales. The literature review and the results also reveal that companies should not only use traditional marketing tools like advertising through the radio, television and magazines. It will be both more effective and cheaper to use Instagram and YouTube influencers. Nevertheless, managers should be aware of the fact that YouTubers and Instabloggers have to associate with the brand identity. As a result, influencers and companies will be depicted as more credible. Social media are still developing and they offer more and more possibilities to users due to their continuous upgrades.

The conducted research presents the power of influencers who use social media to express their views. Consumer behaviour is impacted by their pictures and videos. Collaboration with YouTubers and Instabloggers is an effective marketing tool which should be used by brands. Especially if their targeted group is represented by young people, the most frequent users of social media.

As far as study limitations are concerned, there are a few which have to be mentioned. The main limitation of this study is the sample size in the conducted research as most of participants represented Millennials. Consequently, the results of my study are not representative enough and conclusions cannot be made for the whole population. Moreover, participants were residents of big cities, which also could have impacted the results. Future research should employ a larger and more diverse sample.

Future research should further investigate the impact of influencers. The study could examine an influence of bloggers' and vloggers' negative reviews on buying decisions. It would also be useful to see how other social media (like Facebook, Pinterest) affect consumers. 


\section{References}

Belch, G.E., \& Belch, M. (2011). Advertising and promotion: An integrated marketing communication perspective ( $9^{\text {th }}$ ed.). New York, NY: McGraw-Hill, Irwin.

Bernoff, J., \& Li, C. (2008). Harnessing the power of the oh-so-social web. MIT Sloan, 49(3), 35-42.

Blythe, J. (2013). Consumer behaviour. Los Angeles: SAGE.

Cheung, C., \& Dimple, T. (2012). The impact of electronic word-of-mouth communication: A literature analysis and integrative model. Decision Support Systems, 54, 461-470.

Christodoulides, G., Michaelidou, N., \& Argyriou, E. (2012). Cross-national differences in e-WOM influence. European Journal of Marketing, 46, 1689-1707.

Churchill, G., \& Peter, P. (1984). Research design effects on the reliability of rating scales: A meta-analysis. Journal of Marketing Research, 21(4), 360-375.

Dehghani, M., Khorram Niaki, M., Ramezani, I., \& Sali, R. (2016). Evaluating the influence of YouTube advertising for attraction of young customers. Computers in Human Behavior, 59, 165-172.

Ennew, Ch., Banerjee, A., \& Li, D. (2000). Managing word of mouth communication: Empirical evidence from India. International Journal of Bank Marketing, 18, 75-83.

Freber, K., Graham, K., McGaughey K., \& Freberg, L. (2010). Who are the social media influencers? A study of public perceptions of personality. Public Relations Review, 37(1), 90-92.

Halvorsen, K., Hoffmann, J., Coste-Manière, I., \& Stankeviciute, R. (2013). Can fashion blogs function as marketing to influence consumer behavior? Evidence from Norway. Journal of Global Fashion Marketing: Briding Fashion and Marketing, 4, 211-224.

Haugtvedt, C.P., Machleit, K.A., \& Yalch, R.F. (2005). Online consumer psychology: Understanding and influencing consumer behavior in the virtual world. Mahwah, NJ: Lawrence Erlbaum Associates.

Heinonen, K. (2011). Consumer activity in social media: Managerial approaches to consumers' social media behavior. Journal of Consumer Behaviour, 10, 356-364.

Hsu, Ch., Lin, J., \& Chiang, H. (2013). The effects of blogger recommendations on consumers' online shopping intentions. Emerald Internet Research, 23(1), 69-88.

Jansen, B., \& Zhang M. (2009). Twitter power: Tweets as electronic word of mouth. Journal of the American Society for Information Science and Technology, 60(11), 2169-2188.

Kim, A., \& Johnson, K. (2016). Power of consumers using social media: Examining the influences of brand-related user-generated content on Facebook. Computers in Human Behavior, 58, 98-108.

Kim, J., Herr, P., \& Kardes F. (1991). Effects of word-of-mouth and product-attribute information on persuasion: An accessibility-diagnosticity perspective. Journal of Consumer Research, 14, 454-62.

Lee, J., \& Watkins, B. (2016). YouTube vloggers' influence on consumer luxury brand perceptions and intentions. Journal of Business Research, 69, 5753-5760.

Lee, M., \& Youn, S. (2009). Electronic word of mouth (eWOM): How eWOM platforms influence consumer product judgement. International Journal of Advertising, 28, 473-499.

Liu, Y. (2006). Word-of-mouth for movies: Its dynamics and impact on box office revenue. Journal of Marketing, $70,74-89$.

Mersey, R.D., Malthouse, E.C., \& Calder, B.J. (2010). Engagement with online media. Journal of Media Business Studies, 7, 39-56.

Richins, M.L., \& Root-Shaffer, T. (1988). The role of involvement and opinion leadership in consumer word-ofmouth: An implicit model made explicit. Advances in Consumer Research, 15, 32-36.

Sandes, F., \& Urdan, A. (2013). Electronic word-of-mouth impacts on consumer behavior: Exploratory and experimental studies. Journal of International Marketing, 25, 181-197.

Stewart, D.W., \& Pavlou, P.A. (2002). From consumer response to active consumer: Measuring the effectiveness of interactive media. Journal of the Academy of Marketing Science, 30(4), 376-396.

Sun, T., Youn, S., Wu, G., \& Kuntaraporn, M. (2006). Online word-of-mouth (or mouse): An exploration of its antecedents and consequences. Journal of Computer-Mediated Communication, 11, 1104-1127.

Vinerean, S., Cetina, I., Dumitrescu, L., \& Tichindelean, M. (2013). The effects of social media marketing on online consumer behavior. International Journal of Business and Management, 8(14), 66-79.

Wangenheim, F. (2005). Postswitching negative word of mouth. Journal of Service Research, 8, 67-78.

Wiley, J. (2016). Influencer marketing for dummies. New Jersey: John Wiley \& Sons, Inc.

Wyrwisz, J., \& Żydek B. (2016). Serwis YouTube w komunikacji marketingowej organizacji - korzyści i ograniczenia. Handel Wewnętrzny, 3(362), 413-424.

Zalega, T. (2013). Nowe trendy i makrotrendy w zachowaniach konsumenckich gospodarstw domowych w XXI wieku. Konsumpcja i rozwój, 5(2), 15-16. 


\section{Internet sites:}

Internet World Stats, Usage and Population Statistics. (2018). Internet users in the world. Retrieved on June 30, 2018 from https://www.internetworldstats.com/stats.htm

Gomez, S. (2018). Selena Gomez profile on Instagram. Retrieved from https:/www.instagram.com/ selenagomez/?hl=pl

Jagłowska, A. (2018). Jaglowska profile on Instagram. Retrieved from https://www.instagram.com/jaglowska/?hl=pl

Jenner, K. (2018). Kenall Jenner profile on Instagram. Retrieved from https://www.instagram.com/ kendalljenner $/$ ?hl $=\mathrm{pl}$

Instagram. (2019). A quick wall through our history as a company. Retrieved from https://instagram-press.com/ our-story/

Słownik Języka Polskiego (2018). Vlog. Retrieved from https://sjp.pwn.pl/sjp/vlog;3284831.html

Sugg, Z. (2018). Zoella channel on YouTube. Retrieved from https://www.youtube.com/user/zoella280390

Tusk, K. (2018). makelifeeasier profile on Instagram. Retrieved from https://www.instagram.com/ makelifeeasier_pl/?hl=pl 